\title{
Elevated mean pulmonary artery pressure in patients with mild-to- moderate mitral stenosis: a useful predictor of worsening renal functions?
}

\author{
Hafif ve orta derecede mitral darlı̆̆ı bulunan hastalarda artmış ortalama pulmoner arter \\ basıncı bozulan böbrek fonksiyonlarını göstermede yararı bir belirteç olabilir mi?
}

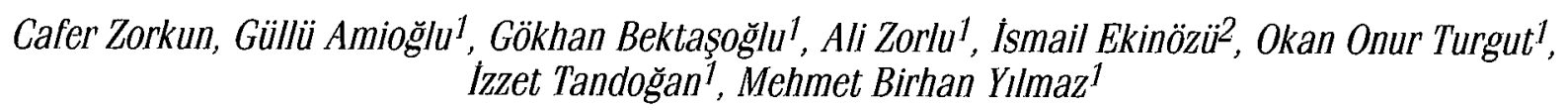

Department of Cardiology, Yedikule Thoracic Diseases\&Surgery Education and Research Hospital, İstanbul-Turkey

${ }^{1}$ Department of Cardiology, Faculty of Medicine, Cumhurivet University, Sivas-Turkey

2Department of Cardiology, Faculty of Medicine, Düzce University, Düzce-Turkey

\section{ABSTRACT}

Objective: Renal dysfunction commonly accompanies the course of cardiac disorders and strongly associates with increased morbidity and mortality. Elevated central venous pressure is related to worsening renal function in patients with heart failure. However, predictors of worsening renal function in mitral stenosis-whose pathophysiologic process is similar to heart failure with regard to right heart dysfunction-are unknown. This study aimed to evaluate whether clinical and echocardiographic parameters might predict worsening renal function in patients with mild-to-moderate mitral stenosis.

Methods: The current study has a prospective cohort design. Sixty consecutive patients ( 9 male, 51 female, mean age $50 \pm 13$ years) with mildto-moderate mitral stenosis were followed up for $34 \pm 13$ months (range 1-60) and their renal functions were monitored. Worsening renal function was defined as a decline in glomerular filtration rate of $\geq 20 \%$ on follow-up. In order to presence or absence of worsening renal functions, study patients divided into two groups. Statistical analysis was performed using the Chi-square, Independent samples $t / M a n n-W h i t n e y ~ U$ tests, univariate and multivariate Cox proportional hazards analyses, receiver operating characteristic (ROC) and Kaplan-Meier curve analyses.

Results: Worsening renal function was observed in 14 patients (23\%). In univariate analysis, male gender, mean pulmonary artery pressure (mPAP), peak tricuspid regurgitation velocity, systolic pulmonary artery pressure, digitalis and antiplatelet usage, right atrial size, and TEl index were determined to be predictors of worsening renal function. In a multivariate Cox proportional hazards model, mPAP (HR=1.136, $95 \% \mathrm{Cl}$ : 1.058-1.220, $p<0.001)$ and male gender ( $H R=4.110,95 \% \mathrm{Cl}: 1.812-9.322, p=0.001)$ were associated with increased risk of worsening renal function during the follow-up period. In ROC curve analysis, the optimal cut-off value of mPAP to predict worsening renal function was measured as more than $21 \mathrm{mmHg}$, with $78.6 \%$ sensitivity and $58.7 \%$ specificity (AUC $0.725,95 \% \mathrm{CI} 0.595-0.838$ ). According to the Kaplan-Meier curve, a significant difference was found between those who had $\mathrm{mPAP}$ of $>21 \mathrm{mmHg}$, and those who did not have, in terms of worsening renal function $(p=0.006)$, and the difference between the groups increased after 30 months of follow-up.

Conclusion: Elevated'mean pulmonary artery pressure at the time of initial evaluation, in patients with mild-to-moderate mitral stenosis, might help to predict worsening renal function. (Anadolu Kardiyol Derg 2013; 13: 457-64)

Key words: Mean pulmonary artery pressure, mitral stenosis, worsening renal function, Cox proportional regression analysis, survival ÖZET

Amaç: Böbrek fonksiyon bozukluğu, sıklıkla kalp hastalıklarına eşlik eder ve yüksek mortalite ve morbiditeye sahiptir. Kalp yetersizliği bulunan hastalarda santral venöz basınç yüksekliği de böbrek fonksiyonlarında bozulmayla ilgilidir. Bununla birlikte; sağ kalbe ait fonksiyon bozukluğu ile kalp yetersizliği bulunan hastalarla benzer patofizyolojik özelliklere sahip mitral darlığı bulunan hastalarda böbrek fonksiyonlarında bozulmayı gösteren belirteçlerin neler olduğu bilinmemektedir. Bu çalışmada, hafif ve orta mitral darlığı bulunan hastalarda klinik ve ekokardiyografik parametrelerin bozulan böbrek fonksiyonlarını göstermedeki verinin araştırılması hedeflenmiştir.

Yöntemler: Bu çalışma prospektif kohort bir dizayna sahiptir. Hafif ve orta derecede mitral darlı̆̆ı bulunan, ortalama yaşları $50 \pm 13$ yıl olan, 9 'u erkek 51'i kadın 60 hastada böbrek fonksiyonları ortalama $34 \pm 13$ ay (1-60 ay) takip edilmiştir. Takip boyunca, glomerüler filtrasyon óranında \%20'den fazla azalma görülmesi böbrek fonksiyonlarında bozulma olarak kabul edilmiştir. Hastalar böbrek fonksiyonlarında bozulma gelişip gelişmemesine göre iki gruba ayrıldı. Istatistiksel analiz olarak Ki-kare, bağımsız gruplarda t/Mann-Whitney U testleri, tek ve çok değişkenli Cox orantısal risk analizleri, ROC ve Kaplan-Meier eğrisi analizleri kullanıldı.

Bulgular: Çalışmaya alınan 14 hastada (\%23) böbrek fonksiyonlarında bozulma tespit edilmiştir. Yapılan tek değişkenli analizlerde; erkek cinsiyet, ortalama pulmoner arter basıncı, pik triküspit regürjitasyon akımı, sistolik pulmoner arter basıncı, dijital ve antitrombositlerin kullanımı, sağ

Address for Correspondence/Yazışma Adresi: Dr. Ali Zorlu, Cumhuriyet Üniversitesi Tıp Fakültesi,

Kardiyoloji Anabilim Dalı, Sivas-Türkive Phone: +90 5064183409 Fax: +90 3462191268 E-mail: dralizorlu@gmail.com

Accepted Date/Kabul Tarihi: 17.12.2012 Available Online Date/Çevrimiçi Yayın Tarihi: 27.05.2013

(C) Telif Hakkı 2013 AVES Yayıncıllk Ltd. SSti. - Makale metnine unw.anakarder.com web sayfasından ulaşılabilir. (C) Copyright 2013 by AVES Yaymcillk Ltd. - Available on-line at www.anakarder.com doi:10.5152/akd.2013.144 
atriyum boyutları ve TEl indeksi'nin böbrek bozıkluklarında bozulmayı gösterdiği saptanmıştır. Çok değişkenli orantısal Cox risk modeli analizleri de, takiృ döneminde erkek cinsiyet ve ortalama pulmoner arter basıncının böbrek fonksiyonlarında bozulma riskindeki artış ile ilişkili olduğunu gös-ermiştir. ROC analizinde, mPAP için kötüleşen böbrek fonksiyonunu gösteren optimal cut-off değeri \% 78,6 duyarlılık ve \%58,7 özgüllük ile (AUC $0,725, \% 95 \mathrm{Cl} 0,595-0,838)>21 \mathrm{mmHg}$ olarak ölçüldü. Kaplan-Meier eğrisi ile değerlendirmelerde, mPAP > 21 mmHg olanlar ve olmayanlar arasında renal fonksiyonlarda kötüleşme açısından görülen fark anlamlıydı $(p=0,006)$. Gruplar arasındaki bu fark 30 aylık takip sonrasında daha da arttı.

Sonuç: Hafif ve orta derecede mitral darlığı bulunan hastalarda, ilk değerlendirmede ölçülen artmış ortalama pulmoner arter basıncı, bozulan böbrek fonksiyonlarını göstermede yararlı olabilir. (Anadolu Kardivol Derg 2013; 13: 457-64)

Anahtar kelimeler: Ortalama pulmoner arter basıncı, mitral darlığı, böbrek fonksiyon bozukluğu, Cox orantısal hazard regresyon analizi, sağ kalın

\section{Introduction}

The incidence of acute rheumatic fever, and consequently of rheumatic valvular heart diseases, in developed countries has declined over the past decade. Although the occurrence of rheumatic heart diseases, including rheumatic mitral stenosis (MS), has declined in developed countries, it has remained a significant public health problem in developing ones (1). Symptoms of MS usually occur after a latent period following an initial acute rheumatic fever episode. This period might take more than 15 years. During this asymptomatic period, mitral valve area (MVA) reduces gradually. Clinical symptoms suggestive of MS occur when MVA of less than $2 \mathrm{~cm}^{2}$, and the appearance cf the diastolic pressure gradient between the left atrium and left ventricle, have resulted in a transmitral peak velocity of greater than $1 \mathrm{~m} / \mathrm{sec}$. Rates of 5-, 10- and 15-year survival with sole medical therapy (without surgery) were $44 \%, 32 \%$, and $19 \%$, respectively (2).

It is well known that renal dysfunction frequently accompanies the course of cardiac disorders and is strongly associated with morbidity and mortality (3-6). Worsening renal function (WRF) most commonly occurs in heart failure (HF) as a result of a complex irteraction between the heart and kidneys. Recently published studies in HF have clarified its pathophysiology and underlined the importance of venous congestion, which can also be observed in MS due to increased right heart afterload (7-9). The relation between venous congestion and renal dysfunction has been shown in experimental studies $(10,11)$. These studies suggest that iatrogenically induced hypervolemia, and increase in renal vein pressure, lead directly to renal insufficiency independent of cardiac output or renal blood flow. This has also been showr to be a reversible phenomenon because lowering of renal vein pressure immediately improves urine output and glomerular filtration rate $(G F R)(10,11)$. Experimental studies have also indicated that temporary renal vein compression results in reduced sodium excretion, reduced GFR, and reduced renal blood flow (12-14:. Increased venous congestion also causes an increase in renal interstitial pressure, which might lead to a hypoxic state of the renal parenchyma (15-18). Prolonged increases in plasma volume also attenuate several vascular reflexes, leading to an impaired arterial responsiveness, thereby further impairing the effective renal blood flow (19-22).

However, the prognostic significance of WRF and its clinical and echocardiographic determinants in MS are still unknown. In this study, we aimed to evaluate the clinical and echocardiographic parameters which might predict WRF in mild-to-moderate MS.

\section{Methods}

\section{Study design}

This study has a prospective cohort design.

\section{Study population}

Eighty consecutive patients with mild-to-moderate rheumatic MS, who were enrolled as part of another study, were prospectively considered in three participating centers between January 2006-January 2011 (23). Twenty patients (with similar age and gender distribution) from the original cohort declined to participate during the follow-up period. Patients with another severe accompanying valvular disorder, history of coronary artery disease, depressed ejection fraction, history of cardiac surgery, previous diagnosis of pulmonary disease, or previous diagnosis of chronic renal failure, were excluded from the study. Patients with a mitral valve area of $<1 \mathrm{~cm}^{2}$ were also excluded, because these patients required surgical treatment at the time of evaluation. Patients with severe MS who declined surgery were also excluded because these patients already had low cardiac output lauthors of this manuscript were considered that this might influence renal functions earlier than expected and could obscure other parameters' significance in determining worsening renal function). Therefore, 60 consecutive patients were enrolled. Patients were evaluated at every 6 months, unless any clinical deterioration and increase in symptoms were observed. The GFR of each participant was followed up at each visit.

The study protocol had been approved by the institutional ethics committee, and written informed consents were taken from all participants of this prospective observational cohort.

\section{GFR assessment}

The GFR was calculated according to the Modification of Diet in Renal Disease (MDRD) formula (86.3 $\times$ sCr $^{-1.154} \times$ age $^{-0.203}$, female: MDRDx0.742, black or non-white: MDRDx1.212). Worsening of renal function was defined as a decline in GFR of $\geq 20 \%$ on follow-up.

\section{Clinical examinations}

Clinical parameters including age, gender, height, weight, body surface area, body mass index, and presence and dura- 
tions of comorbid disorders such as hypertension, diabetes mellitus, hyperlipidemia, smoking, characteristics of cardiac rhythm, and applied treatment as antiplatelets, beta-blockers, angiotensin-converting enzyme (ACE) inhibitors / angiotensin receptor blockers (ARB), diuretics, calcium channel blockers, digitalis, and warfarin were carefully evaluated and recorded.

\section{Echocardiography}

Echocardiographic examinations were performed with a cardiac ultrasound system (Vivid 7, GE Healthcare, Wauwatosa, WI, US) to evaluate chamber quantification with a defined protocol $(11,24)$ by a physician who was unaware of patients' renal function. Resting heart rate was $55-85 \mathrm{bpm}$ in all patients during echocardiographic examination. All echocardiograms were recorded and coded by echocardiographers without identities to eliminate interobserver variability. Recorded and coded data were put into random order by computer assistance and evaluated off-line by an expert echocardiographer. MVA was calculated by the two-dimensional planimetry method, and if the image quality was not sufficient, the Doppler pressure half time method was used (25). Transmitral gradients were calculated by the modified Bernoulli equation (26). Accompanying valvular regurgitations were quantified according to recent guidelines and categorized as mild-moderate (27). The modified Bernoulli equation derived from the tricuspid regurgitation jet velocity and estimated right atrial pressure from inferior vena cava collapsibility was used in determining systolic pulmonary artery pressure (sPAP) (28). Mean pulmonary artery pressure (mPAP) was calculated by the Masuyama method (29). Tricuspid annulus velocities (via tissue Doppler), right ventricular outflow timevelocity integral, Tei index, ejection times, intervals, and tricuspid annular plane systolic excursion were measured accordingly in all patients (30-33). Echocardiographic parameters at the time of initial evaluation were used in statistical analysis, as predictors of WRF during follow-up.

\section{Statistical analysis}

All statistical procedures were performed using SPSS software version 15.0 (SPSS Inc., Chicago, IL). Continuous variables were expressed as mean \pm standard deviation or median (interquatile range) in the presence of abnormal distribution, categorical variables as percentages. Comparisons between groups of patients were made by use of a Chi-square test for categorical variables, an independent samples t-test for normally distributed continuous variables, and the Mann-Whitney $U$ test when the distribution was skewed. Univariate Cox proportional hazards analysis was used to quantify the association of variables with worsening renal function. Variables found to be significant at the $p<0.1$ level in univariate analysis were used in a multivariate Cox proportional hazards model with a forward stepwise method in order to determine the independent predictors of WRF. Receiver operator characteristic (ROC) curve analysis was performed to identify the optimal cut-off point of mPAP (at which sensitivity and specificity would be maximal) for the prediction of WRF. Areas under the curve $(A \cup C)$ were calculated as measures of the accuracy of the tests. We compared the AUC by use of the $Z$ test. Kaplan-Meier curves were used to show the development of WRF in two patient subgroups, defined as having no increased $(\leq 21$ $\mathrm{mmHg}$ ) or increased (>21 mmHg) mPAP based on a cut off value. A p-value of 0.05 was considered as statistically significant.

\section{Results}

\section{Baseline clinical characteristics and echocardiographic parameters}

Sixty mild-to-moderate MS patients were followed up for a mean period of $34 \pm 13$ months (range 1-60). The mean age of the study population was $50 \pm 13$ years ( $85 \%$ females, $15 \%$ males). The mean MVA and mean transmitral gradient of the study population were $1.6 \pm 0.2 \mathrm{~cm}^{2}$ and $6.4 \pm 2.9 \mathrm{mmHg}$, respectively. Comparison of patients' baseline clinical characteristics and echocardiographic parameters, according to the presence of WRF, has been shown in Table 1 and Table 2. Worsening renal function on follow-up was more frequent in patients of male gender, or with a history of digitalis use $(p=0.025$ and $p=0.044$, respectively. Maximum tricuspid regurgitation velocity (TR max velocity), SPAP and mPAP were higher in patients with worsening renal function $(p<0.05)$. Other baseline clinical and echocardiographic parameters were similar between groups (Table 1 and 2).

\section{Regression analyses for the development of worsening} renal function

Results of the univariate and multivariate Cox proportional hazards analyses have been shown in Table 3. Male gender, mPAP, TR max velocity, SPAP, digitalis and antiplatelet agent usage, right atrial diameter, and Tei index were found to be univariate predictors of WRF. In the multivariate Cox proportional hazards model, mPAP (HR=1.136, $95 \% \mathrm{Cl}$ : 1.058-1.220, $p<0.001)$ and male gender $(H R=4.110,95 \% \mathrm{Cl}: 1.812-9.322$, $p=0.001$ ) were associated with an increased risk of WRF during follow-up.

\section{ROC curve for mPAP to predict worsening renal function}

According to the ROC curve analysis, the optimal cut-off value of mPAP to predict WRF was measured as more than 21 $\mathrm{mmHg}$, with $78.6 \%$ sensitivity and $\mathbf{5 8 . 7 \%}$ specificity (AUC 0.725 , $95 \% \mathrm{Cl} 0.595-0.838$, Fig. 1). On the other hand, mPAP of $>36.21$ $\mathrm{mmHg}$ was found to have $100 \%$ specificity for WRF on follow-up, though sensitivity was low (14.3\%).

\section{Survival analysis}

According to the Kaplan-Meier curve, a significant difference was found between those who had mPAP of $>21 \mathrm{mmHg}$, and those who did not, in terms of worsening renal function $(p=0.006)$, and the difference between the groups became bigger after 30 months of follow-up (Fig. 2). 
Table 1. Baseline characteristics and differences between patients who did and did not develop worsening renal function during follow-up

\begin{tabular}{|c|c|c|c|}
\hline Variables & $\begin{array}{l}\text { Patients without worsening renal } \\
\text { function on follow up ( } n=46 \text { ) }\end{array}$ & $\begin{array}{l}\text { Patients with worsening renal } \\
\text { function on follow up ( } n=14 \text { ) }\end{array}$ & *p \\
\hline Mean age, years & $49 \pm 12$ & $52 \pm 16$ & 0.486 \\
\hline Male gender, $n(\%)$ & $4(9)$ & $5(36)$ & 0.025 \\
\hline Heigh & $158 \pm 5$ & $161 \pm 10$ & 0.387 \\
\hline Weiglit, kg & $73 \pm 14$ & $70 \pm 15$ & $0.471^{\circ}$ \\
\hline $\mathrm{BSA}, \mathrm{m}^{2}$ & $1.8 \pm 0.1$ & $1.7 \pm 0.2$ & 0.598 \\
\hline BMI, $\mathrm{kg} / \mathrm{m}^{2}$ & $29 \pm 6$ & $27 \pm 6$ & 0.245 \\
\hline Follow-up time, months & $34 \pm 14$ & $36 \pm 10$ & 0.592 \\
\hline Presence of hypertension & 18(39) & $8(57)$ & 0.235 \\
\hline Baseline GFR, $\mathrm{mL} / \mathrm{min} / \mathrm{m}^{2}$ & $107 \pm 34$ & $100 \pm 50$ & 0.570 \\
\hline Final GFR, $\mathrm{mL} / \mathrm{min} / \mathrm{m}^{2}$ & $112 \pm 35$ & $57 \pm 33$ & $<0.001$ \\
\hline Change of GFR, \%, & $0(-12.5 / 25)$ & $-40(-57 /-31)$ & $<0.001$ \\
\hline Presence of diabetes mellitus & $6(13)$ & $1(7)$ & 1.000 \\
\hline Duration of diabetes mellitus, years & $3 \pm 6$ & $4 \pm 10$ & 0.804 \\
\hline Hypenlipidemia, n (\%) & $11(24)$ & $3(21)$ & 1.000 \\
\hline Duration of hyperlipidemia, years & $1.5 \pm 2$ & $1 \pm 1$ & 0.678 \\
\hline Smoking, $n(\%)$ & $5(11)$ & $2(14)$ & 0.660 \\
\hline Duration of smoking, years & $5 \pm 10$ & $12 \pm 20$ & 0.759 \\
\hline Atrial fibrillation, $n(\%)$ & $18(39)$ & $5(36)$ & 0.817 \\
\hline Antipsatelet agents, $n(\%)$ & $34(74)$ & $7(50)$ & 0.111 \\
\hline Beta jlockers, $n(\%)$ & $27(59)$ & $8(57)$ & 0.918 \\
\hline ACE inhibitors/ ARB, $n(\%)$ & $16(35)$ & $5(36)$ & 1.000 \\
\hline Diuretics, $\mathrm{n}(\%)$ & $11(24)$ & $2(14)$ & 0.713 \\
\hline Calcium canal blockers, $n(\%)$ & $13(28)$ & $3(21)$ & 0.740 \\
\hline Digitalis, $n(\%)$ & $5(11)$ & $5(36)$ & 0.044 \\
\hline Warfarin, $n(\%)$ & $21(46)$ & $5(36)$ & 0.508 \\
\hline
\end{tabular}

\section{Discussion}

In this study, we aimed to evaluate whether clinical and echocardiographic parameters might predict WRF in patients with mild-to-moderate mitral stenosis. Male gender, mPAP, TRmax velocity, SPAP, digitalis and antiplatelet agent usage, right atrial diameter and TEI index were found to be univariate predictors of worsening renal function. However, even after controlling these parameters, we demonstrated that only mPAP and male gender were independently associated with an increased risk of WRF during follow-up in patients with mild-to-moderate mitral stenosis.

The kidney and the heart are two closely interrelated organs. It is well known that any disorder affecting one of the two deteriorates the other's functional status. Deterioration of this close interrelation between these two organ systems is known as "cardio-renal syndrome," and studies in HF have clarified the pathophysiological mechanisms behind this syndrome. It has been thought that renal dysfunction in $\mathrm{HF}$ is attributable to low cardiac output, which consequently causes reduction in blood flow and renal perfusion pressure $(9,34)$. Decreased cardiac output also activates the renin-angiotensin-aldosterone system and the sympathetic nervous system, which in turn causes congestion and constriction in afferent arterioles. These results in further decreases in renal perfusion pressure (34). Theoretically, the above-mentioned pathophysiological mechanism is valid; however, recent studies suggest different mechanisms. Heywood et al., (35) have shown that renal dysfunction is similar in patients with systolic and diastolic dysfunction; this result suggests mechanisms other than low cardiac output. Recently published HF studies have explained the role of venous congestion in renal dysfunction $(7-9,36,37)$. Some other studies have suggested right atrial and central venous pressure, rather than 
Table 2. Comparison of the echocardiographic parameters between patients who did and did not develop worsening renal function during follow-up

\begin{tabular}{|c|c|c|c|}
\hline Variables & $\begin{array}{c}\text { Patients without worsening renal } \\
\text { function on follow up ( } n=46 \text { ) }\end{array}$ & $\begin{array}{l}\text { Patients with worsening renal } \\
\text { function on follow up ( } n=14)\end{array}$ & ${ }^{*} \mathrm{p}$ \\
\hline E velocity, $\mathrm{m} / \mathrm{sec}$ & $1.3 \pm 0.7$ & $1.4 \pm 0.5$ & 0.882 \\
\hline A velocity, $\mathrm{m} / \mathrm{sec}$ & $1.5 \pm 0.5$ & $1.4 \pm 0.3$ & 0.593 \\
\hline E/A ratio & $0.8 \pm 0.4$ & $0.9 \pm 0.3$ & 0.648 \\
\hline Ejection fraction, $\%$ & $55 \pm 7$ & $56 \pm 8$ & 0.647 \\
\hline LV diastolic volume, $\mathrm{mL}$ & $92 \pm 24$ & $96 \pm 39$ & 0.685 \\
\hline LV systolic volume, $\mathrm{mL}$ & $41 \pm 14$ & $39 \pm 14$ & 0.602 \\
\hline Left atrial diameter $4 \mathrm{Cl}, \mathrm{cm}$ & $4.7 \pm 0.8$ & $4.6 \pm 0.8$ & 0.667 \\
\hline Left atrial diameter $4 \mathrm{C} 2, \mathrm{~cm}$ & $6.8 \pm 1.0$ & $6.7 \pm 0.9$ & 0.915 \\
\hline Area of left atrium, $\mathrm{cm}^{2}$ & $34 \pm 47$ & $28 \pm 9$ & 0.610 \\
\hline Right atrial diameter $4 \mathrm{Cl}, \mathrm{cm}$ & $3.7 \pm 0.9$ & $4.3 \pm 0.8$ & 0.058 \\
\hline Right atrial diameter $4 \mathrm{C} 2, \mathrm{~cm}$ & $5.3 \pm 0.9$ & $5.5 \pm 1.0$ & 0.364 \\
\hline Area of right atrium, $\mathrm{cm}^{2}$ & $19 \pm 7$ & $23 \pm 8$ & 0.101 \\
\hline RV diameter $\mathrm{D} 2, \mathrm{~cm}$ & $3.1 \pm 0.6$ & $3.4 \pm 0.5$ & 0.266 \\
\hline$E^{\prime}$ velocity, $\mathrm{m} / \mathrm{sec}$ & $0.15 \pm 0.04$ & $0.16 \pm 0.04$ & 0.566 \\
\hline$A^{\prime}$ velocity, $\mathrm{m} / \mathrm{sec}$ & $0.20 \pm 0.2$ & $0.16 \pm 0.06$ & 0.565 \\
\hline $\mathrm{S}$ velocity, $\mathrm{m} / \mathrm{sec}$ & $0.15 \pm 0.15$ & $0.13 \pm 0.04$ & 0.664 \\
\hline RV Ejection time, msec & $287 \pm 41$ & $291 \pm 47$ & 0.798 \\
\hline IVCT, msec & $74 \pm 20$ & $71 \pm 11$ & 0.624 \\
\hline IVRT, msec & $77 \pm 19$ & $73 \pm 19$ & 0.479 \\
\hline TEl index & $0.52 \pm 0.13$ & $0.46 \pm 0.17$ & 0.189 \\
\hline RV fractional area change, $\%$ & $16 \pm 4$ & $18 \pm 4$ & 0.174 \\
\hline TR max velocity, $\mathrm{m} / \mathrm{sec}$ & $2.7 \pm 0.3$ & $3.1 \pm 0.5$ & 0.007 \\
\hline RVOT TVI, cm & $18 \pm 5$ & $17 \pm 4$ & 0.590 \\
\hline $\mathrm{PV} \max , \mathrm{m} / \mathrm{sec}$ & $0.8 \pm 0.1$ & $0.8 \pm 0.1$ & 0.591 \\
\hline PAcT, msec & $112 \pm 25$ & $97 \pm 25$ & 0.051 \\
\hline TAPSE, cm & $2.2 \pm 0.6$ & $2.1 \pm 0.5$ & 0.541 \\
\hline Aortic regurtitation, mild/moderate & $28 / 18$ & $7 / 7$ & 0.680 \\
\hline Mitral regurtitation, mild/moderate & $25 / 21$ & $8 / 6$ & 1.000 \\
\hline Area of mitral regurtitation, $\mathrm{cm}^{2}$ & $4.8 \pm 2.8$ & $4.9 \pm 3.8$ & 0.881 \\
\hline Tricuspid regurtitation, mild/moderate & $33 / 13$ & $8 / 6$ & 0.338 \\
\hline Area of tricuspid regurtitation, $\mathrm{cm}^{2}$ & $4.2 \pm 3.6$ & $4.3 \pm 2.2$ & 0.919 \\
\hline MVA planimetric, $\mathrm{cm}^{2}$ & $1.6 \pm 0.2$ & $1.5 \pm 0.2$ & 0.525 \\
\hline MVA PHT, $\mathrm{cm}^{2}$ & $1.6 \pm 0.3$ & $1.5 \pm 0.3$ & 0.522 \\
\hline Maximum MV gradient, $\mathrm{mmHg}$ & $13.7 \pm 5.1$ & $15.0 \pm 6.0$ & 0.434 \\
\hline Mean MV gradient, mmHg & $6.2 \pm 2.8$ & $6.9 \pm 3.6$ & 0.460 \\
\hline Systolic PA pressure, $\mathrm{mmHg}$ & $30.6 \pm 7.9$ & $39 \pm 13.9$ & 0.048 \\
\hline Mean PA pressure, $\mathrm{mmHg}$ & $20.7 \pm 5.3$ & $26.4 \pm 8.1$ & 0.003 \\
\hline \multicolumn{4}{|c|}{ 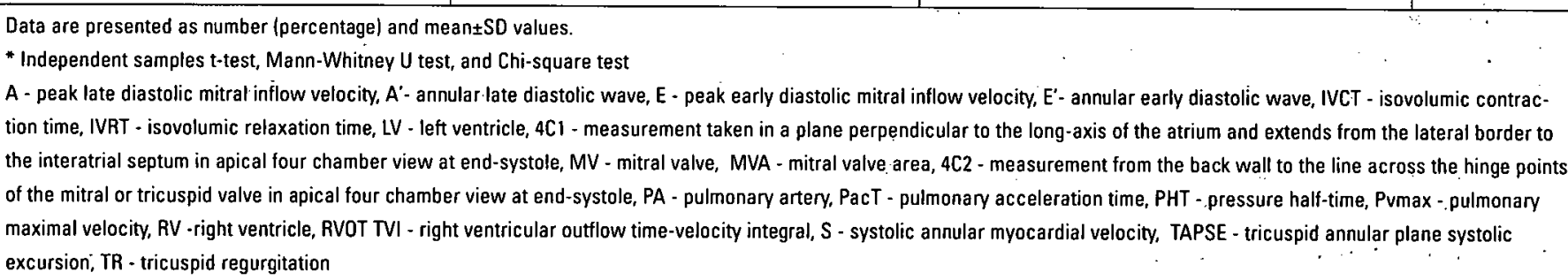 } \\
\hline
\end{tabular}


Table 3. Univariate and multivariate predictors of worsening renal function

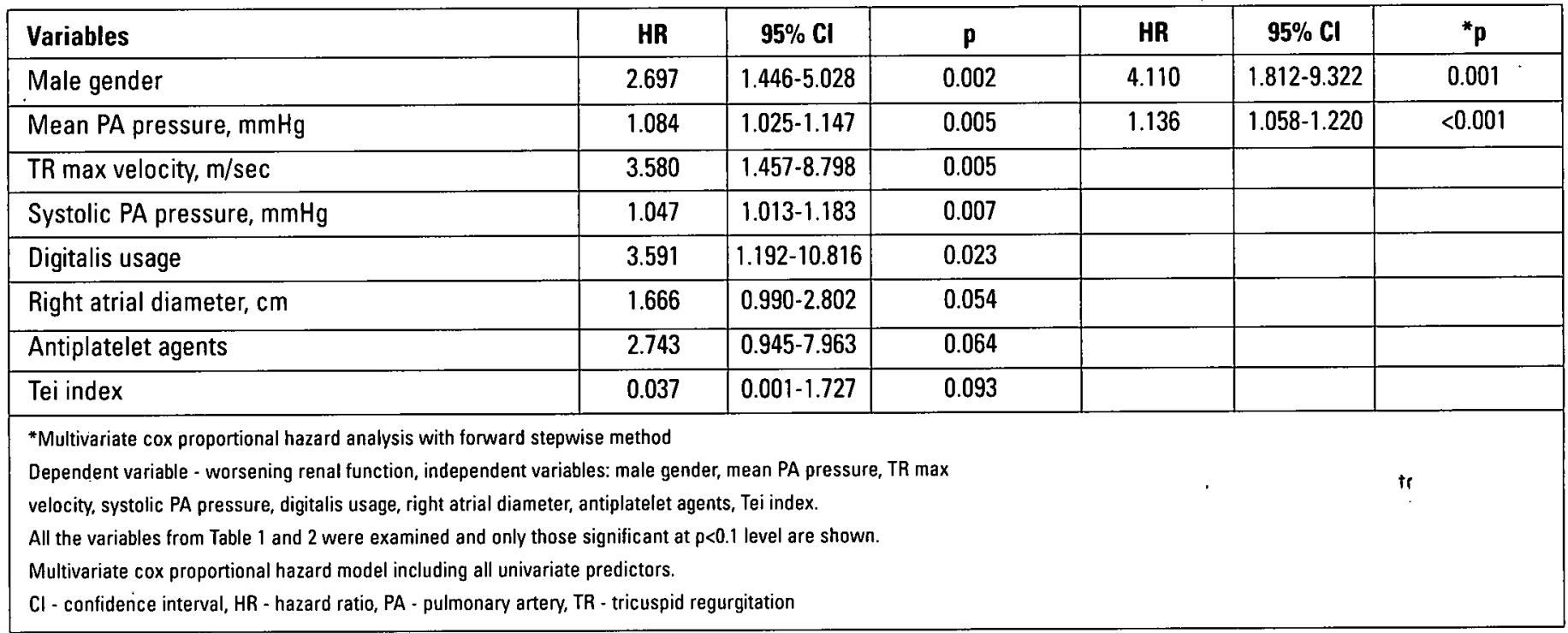

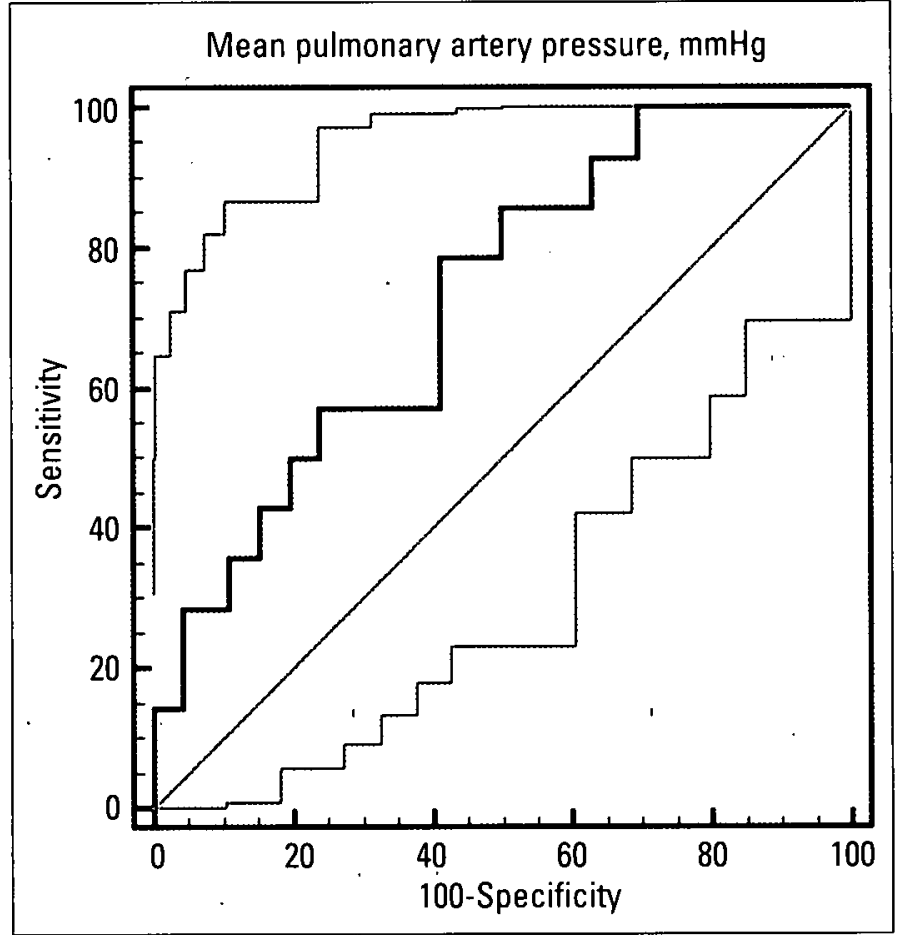

Figure 1. ROC Curve for mean pulmonary artery pressure to predict worsening renal function (AUC-0.725, 95\% CI 0.595-0.838)

cardiac index, as the main predictors of worsening renal function $(37,38)$. Increased oxidative stress and inflammation in the tubule-interstitium developed after venous congestion may also have a role in renal dysfunction (39).

Renal dysfunction may also potentially complicate the course of rheumatic MS. Just like in HF, right ventricular dysfunction secondary to increased right heart afterload, and venous congestion, are also common findings of MS. However, the potential role of echocardiography in predicting WRF in MS is unknown. In this study, we investigated clinical and echocardiographic indices of WRF in MS. In our study, mPAP was found to be an independent

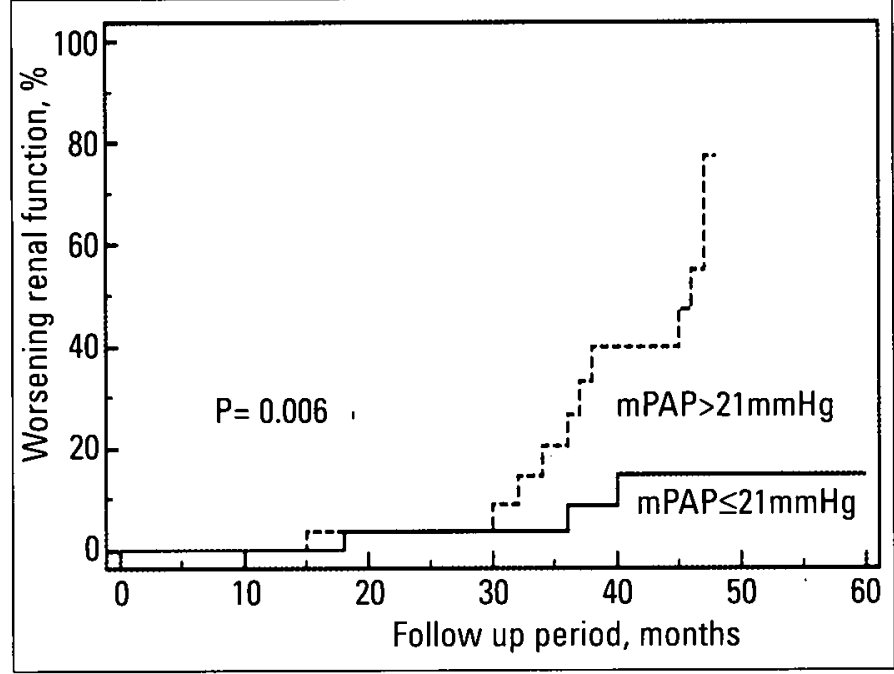

Figure 2. Ratio of those with worsening renal function on follow-up mPAP - mean pulmonary artery pressure

predictor of WRF. Systolic PAP and TR max velocity were other predictors in univariate analysis, though they lost their significance after multivariate analysis. On the other hand, in this study, echocardiographic indices of MS severity including transmitral gradients and valve area, as well as left atrial diameters, had no influence in predicting WRF. These findings were consistent with the above-mentioned data derived from $\mathrm{HF}$ studies, which proved the role of venous congestion and right ventricular dysfunction in WRF. It is notable that cardiac output may have a potential role in worsening renal function; however, we excluded patients with severe MS since these patients needed intervention at the time of evaluation. In our study, right ventricular diameter was. within normal range and did not differ between groups. This was also true for TAPSE and Tei indices. These findings suggest that right ventricular systolic function was relatively preserved at the time of evaluation; however, an afterload mismatch of the right ventri- 
cle, in the form of increased pulmonary pressure, was already there. This increased afterload seemed to bring about right ventricular diastolic dysfunction, which in turn increased right atrial pressures and caused venous congestion. Increased transverse right atrial diameter, observed in this study, supports this hypothesis (Table 2). The right atrial area was also increased in patients with WRF, though it could not reach statistical significance $(p=0.101)$. We think invasive measurement of right atrial pressure might clarify this hypothesis.

\section{Study limitations}

Although a lack of invasive measurements was the major limitation of our study, we did not consider invasive assessment, since it might cause ethical problems if performed in cases of mild-to-moderate MS. Central venous pressure and inferior vena cava diameters, which remain other important study limitations, were also not recorded in our study. Because right ventricular systolic function was preserved, this issue was overlooked. Male gender was also found to be a predictor of WRF; however, it is better not to generalize about this, since there were relatively few male patients in the cohort, which is another limitation of this study. The number of patients enrolled in this study was another limitation; therefore, our findings should not be generalized. These findings should be supported by further studies conducted with a sufficient number of patients.

\section{Conclusion}

Increased mPAP at the time of evaluation, in patients with mild-to-moderate MS, seems to predict WRF during follow-up; hence, we think close monitoring of these patients, particularly those with mPAP of $>36.2 \mathrm{mmHg}$-which as a rule designates very high specificity in test results-may be useful in terms of renal function.

\section{Conflict of interest: None declared.}

\section{Peer-review: Externally peer-reviewed.}

Authorship contributions: Concept - M.B.Y., C.Z., A.Z.; Design - M.B.Y., G.A., G.B.; Supervision - M.B.Y., I.T., 0.O.T.; Resource - I.T., M.B.Y.; Material - G.A.; Data collection\&/or Processing - G.A., G.B.; Analysis \&/or interpretation - A. Z.; Literature search - C.Z., I.E.; Writing - C.Z., A.Z.; Critical review - O.O.T., M.B.Y., A.Z;; Other - I.E.

\section{References}

1. Fieldman T. Rheumatic heart disease. Curr Opin Cardiol 1996; 11: 126-30.

2. Chandrashekhar Y, Westaby S, Narula J. Mitral stenosis. Lancet 2009; 374: 1271-83.

3. Blasco L, Sanjuan R, Carbonell N, Solís MA, Puchades MJ, Torregrosa I, et al. Estimated Glomerular Filtration Rate in ShortRisk Stratification in Acute Myocardial Infarction. Cardiorenal Med 2011; 1: 131-8.
4. Damman K, Jaarsma T, Voors AA, Navis G, Hillege HL, van Veldhuisen DJ; $C O A C H$ investigators. Both in- and out-hospital worsening of renal function predict outcome in patients with heart failure: results from the Coordinating Study Evaluating Outcome of Advising and Counseling in Heart Failure (COACH). Eur $\mathrm{J}$ Heart Fail 2009; 11: 847-54

5. Smilde TD, Hillege HL, Navis G, Boomsma F, de Zeeuw D, van Veldhuisen DJ. Impaired renal function in patients with ischemic and non-ischemic chronic heart failure: association with neurohormonal activation and survival. Am Heart J 2004; 148: 165-72.

6. Hillege HL, Girbes AR, de Kam PJ, Boomsma F, de Zeeuw D, Charlesworth $A$, et al. Renal function, neurohormonal activation, and survival in patients with chronic heart failure. Circulation 2000; 102: 203-10.

7. Mullens W, Abrahams Z, Francis GS, Sokos G, Taylor DO, Starling $\mathrm{RC}$, et al. Importance of venous congestion for worsening of renal function in advanced decompensated heart failure. J Am Coll Cardiol 2009; 53: 589-96.

8. Damman $K$, Voors AA, Hillege HL, Navis G, Lechat $P$, van Veldhuisen $D J$, et al. Congestion in chronic systolic heart failure is related to renal dysfunction and increased mortality. Eur J Heart Fail 2010; 12: 974-82.

9. Damman K, Navis G, Smilde TD, Voors AA, van der Bij W, van Veldhuisen DJ, et al. Decrease cardiac output, venous congestion and the association with renal impairment in patients with cardiac dysfunction. Eur J Heart Fail 2007; 9: 872-8.

10. Firth JD, Raine AE, Ledingham JG. Raised venous pressure: a direct cause of renal sodium retention in oedema? Lancet 1988; 1: 1033-5.

11. Winton FR. The influence of venous pressure on the isolated mammalian kidney. J Physiol 1931; 72: 49-61.

12. Burnett JC Jr, Haas JA, Knox FG. Segmental analysis of sodium reabsorption during renal vein constriction. Am J Physiol 1982; 243: 19-22.

13. Wathen RL, Selkurt EE. Intrarenal regulatory factors of salt excretion during renal venous pressure elevation. Am J Physiol 1969; 216: 1517-24.

14. Burnett JC Jr, Knox FG. Renal interstitial pressure and sodium excretion during renal vein constriction. Am J Physiol 1980; 238: 279-82.

15. Maxwell MH, Breed ES, Schwartz IL. Renal venous pressure in chronic congestive heart failure. J Clin Invêst 1950; 29: 342-8.

16. Fiksen-Olsen MJ, Romero JC. Renal effects of prostaglandin inhibition during increases in renal venous pressure. Am J Physiol 1991; 260: 525-9.

17. Fiksen-OIsen MJ, Strick DM, Hawley H, Romero JC. Renal effects of angiotensin 11 inhibition during increases in renal venous pressure. Hypertension 1992; 19: II137-41.

18. Hamza SM, Kaufman S. Effect of mesenteric vascular congestion on reflex control of renal blood flow. Am J Physiol Regul Integr Comp Physiol 2007; 293: 1917-22.

19. Charkoudian N, Martin EA, Dinenno FA, Eisenach JH, Dietz NM, Joyner MJ. Influence of increased central venous pressure on baroreflex control of sympathetic activity in humans. Am J Physiol Heart Circ Physiol 2004; 287: 1658-62.

20. Creager MA, Creager SJ. Arterial baroreflex regulation of blood pressure in patients with congestive heart failure. J Am Coll Cardiol 1994; 23: 401-5.

21. Cody RJ, Ljungman S, Covit AB, Kubo SH, Sealey JE, Pondolfino K, et al. Regulation of glomerular filtration rate in chronic congestive heart failure patients. Kidney Int 1988; 34: 361-7.

22. Greenberg TT, Richmond WH, Stocking RA, Gupta PD, Meehan JP, Henry JP. Impaired atrial receptor responses in dogs with heart 
failure due to tricuspid insufficiency and pulmonary artery stenosis. Circ Res 1973; 32: 424-33.

23. Zorlu A, Amioğlu G, Yılmaz N, Semiz M, Refiker Ege M, Aydın G, et al. The relationship between mean pulmonary artery pressure and quality of life in patients with mitral stenosis. Cardiology 2011; 119: 170-5.

24. Lang RM, Bierig $M$, Devereux RB, Flachskampf FA, Foster $E$, Pellikka PA, et al: American Society of Echocardiography's Nomenclature and Standards Committee; Task Force on Chamber Quantification; American College of Cardiology Echocardiography Committee; American Heart Association; European Association of Echocardiography, European Society of Cardiology. Recommendations for chamber quantification. Eur J Echocardiogr 2006;7: 79-108.

25. Feigenbaum $\mathrm{H}$. Acquired valvular heart disease. In: Feigenbaum $\mathrm{H}$, Editor: Echocardiography, 5th ed. Philadelphia; Lea and Febiger. 1994.p.239.

26. Nichol PM, Gilbert BW, Kisslo JA. Two-dimensional echocardiographic assessment of mitral stenosis. Circulation 1977; 55: $120-8$.

27. Lancellotti P, Moura L, Pierard LA, Agricola E, Popescu BA, Tribouilloy $C$, et al; European Association of Echocardiography. European Association of Echocardiography recommendations for the assessment of valvular regurgitation. Part 2: mitral and tricuspid regurgitation (native valve disease). Eur J Echocardiogr 2010; 11: 307-32.

28. Rivera JM, Vandervoort PM, Mele D, Siu S, Morris E, Weyman AE, et al. Quantification of tricuspid regurgitation by means of the proximal flow convergence method: a clinical study. Am Heart $\mathrm{J}$ 1994; 127: 1354-62.

29. Masuyama T, Kodama K, Kitabatake A, Sato $H$, Nanto $S$, Inoue M. Continuous-wave Doppler echocardiographic detection of pulmonary regurgitation and its application to noninvasive estimation of pulmonary artery pressure. Circulation 1986; 74: 484-92.
30. Milan A, Magnino C, Veglio F. Echocardiographic indexes for the non-invasive evaluation of pulmonary hemodynamics. J Am Soc Echocardiogr 2010; 23: 225-39.

31. Galderisi M, Severino S, Cicala S, Caso P. The usefulness of pulsed tissue Doppler for the clinical assessment of right ventricular function. Ital Heart J 2002; 3: 241-7.

32. Tei $C$. New non-invasive index for combined systolic and diastolic ventricular function. J Cardiol 1995; 26: 135-6.

33. Saxena N, Rajagopalan N, Edelman K, López-Candales A. Tricuspid annular systolic velocity: a useful measurement in determining right ventricular systolic function regardless of pulmonary artery pressures. Echocardiography 2006; 23: 750-5.

34. McCullough PA, Ahmad A. Cardiorenal syndromes. World J Cardiol 2011;3:1-9.

35. Heywood JT, Fonarow GC, Costanzo MR, Mathur VS, Wigneswaran JR, Wynne J;ADHERE Scientific Advisory Committee and Investigators. High prevalence of renal dysfunction and its impact on outcome in 118,465 patients hospitalized with acute decompensated heart failure: a report from the ADHERE database. J Card Fail 2007; 13: 422-30.

36. Maeder MT, Holst DP, Kaye DM. Tricuspid regurgitation contributes to renal dysfunction in patients with heart failure. J Card Fail 2008;14:824-30.

37. Nohria A, Hasselblad V, Stebbins A, Pauly DF, Fonarow GC, Shah M, et al. Cardiorenal interactions: insights from the ESCAPE trial. $J$ Am Coll Cardiol 2008; 51: 1268-74.

38. Testani JM, Khera AV, St John Sutton MG, Keane MG, Wiegers SE, Shannon RP, et al. Effect of right ventricular function and venous congestion on cardiorenal interactions during the treatment of decompensated heart failure. Am J Cardiol 2010; 105: 511-6.

39. Tanaka M, Yoshida $H$, Furuhashi $M$, Togashi N, Koyama M, Yamamoto $S$, et al. Deterioration of renal function by chronic heart failure is associated with congestion and oxidative stress in the tubulointerstitium. Intern Med 2011; 50: 2877-87. 
Copyright of Anatolian Journal of Cardiology / Anadolu Kardiyoloji Dergisi is the property of Aves Yayincilik Ltd. STI and its content may not be copied or emailed to multiple sites or posted to a listserv without the copyright holder's express written permission. However, users may print, download, or email articles for individual use. 